\title{
The African Elephant (Loxodonta africana): Mini-Review of an Endangered Species
}

\author{
Ana Raquel de Sales ${ }^{1}$, Rita Sofia Santos Anastácio², M. J. Pereira ${ }^{*}$ \\ ${ }^{1}$ Department of Biology, University of Aveiro, Aveiro, Portugal \\ ${ }^{2}$ Independent Researcher, Aveiro, Portugal \\ Email: ${ }^{*}$ mverde@ua.pt
}

How to cite this paper: de Sales, A.R., Anastácio, R.S.S. and Pereira, M.J. (2020) The African Elephant (Loxodonta africana): Mini-Review of an Endangered Species. Natural Resources, 11, 317-350. https://doi.org/10.4236/nr.2020.118019

Received: June 23, 2020

Accepted: August 23, 2020

Published: August 26, 2020

Copyright (c) 2020 by author(s) and Scientific Research Publishing Inc. This work is licensed under the Creative Commons Attribution International License (CC BY 4.0).

http://creativecommons.org/licenses/by/4.0/ (c) (i) Open Access

\begin{abstract}
Humankind is responsible for conditioning the distribution of species, including the African elephant. From its great physical form to its fascinating social behaviour, Loxodonta africana can trigger an admiration in some and be undervalued by others, often ending up being a victim of human activities. Increasingly, the apparent impossibility of the coexistence of these two species represents a problem for the conservation of the large African mammal. Here it was reviewed the published bibliography about the African savannah elephant (L. africana), between July 2015 and December 2019. The Web of Science (WoS) database enabled the search for the words "Loxodonta africana". From this research, we obtained 310 articles, 149 of them were analysed. Elephants have characteristics that define its uniqueness that are constantly reported, such as: its cognition and extraordinary memory, factors that influence its movements and its distribution, its specific vocalization and the strong dependence on social connections. Threats to the conservation of the species and the urgency of interventions are also an important subject of discussion. Poaching for ivory represents a major obstacle on conservation and has been drastically reducing the number of elephant populations and causing future consequences for those who thrive. Law enforcement in reducing/prohibit poaching has proven to be insufficient, so there is an urgent need to combat the demand for ivory. Also, it is necessary to bypass the conflict, promote tolerance and enable cohabitation. We believe that educating human populations to better understand the species may be the difference to guarantee a future for the species. Conservationists may be the enablers of these educational actions, however, to make the difference, it is necessary to know the species in detail. Mastering knowledge in these behavioural areas will contribute to improve mitigation strategies, which could make the difference to guarantee a future for the species.
\end{abstract}




\section{Keywords}

Behaviour, Ecosystem Engineer, Environmental Awareness, Human-Wildlife Conflict, Loxodonta africana, Mitigation Strategies, Poaching, Wildlife Conservation

\section{Introduction}

Due to the current conditions of the planet, the ecological impacts in several ecosystems are notorious. Several species are in sharp decline and at risk of extinction. This move towards mass extinction appears to be the repetition of History, but this time, a new threat accelerates these processes: Humankind. Among the main reasons for the loss of biodiversity, we can highlight causes such as habitat destruction, increased pollution and the excessive use of natural resources.

The African savannah elephant is an example of a species that is a victim of this current trend. According to the IUCN Red List, $L$. africana is a species considered vulnerable [1] and, for this reason, the obstacles to its conservation have been studied over the last few years, highlighting anthropogenic threats the major cause of current problems: Human-Wildlife Conflict (HWC) and poaching.

This mammal, known as an ecosystem engineer, has great influence on the landscape and the distribution of species. Its extinction can have serious consequences for other living beings. It is mainly because of its ecological relevance that conservation actions should not be ignored. The difficulty of carrying out interventions in the area stems, in large part, from issues such as poverty, corruption and disinformation.

Direct conflicts between humans and elephants are associated with the difficulty of cohabitation. Human settlements occupy spaces that used to belong to wildlife and wildlife, in turn, tries to benefit from the crops on which human populations depend. In addition, the fear felt by humans in the presence of this large terrestrial mammal contributes to increased tensions.

Environmental management is often not prioritized when it comes to economic benefits-poaching for ivory is an example of this. The consequences of this activity are devastating for the species, which reinforces the need to improve and promote mitigation strategies.

Knowing the species, which is possible through investigations in the area, facilitates protection actions. Thus, information related to the habits of the elephants, their health, their physical characteristics and their behaviour are also important to improve the knowledge of the African elephant and use this information on behalf of the species.

In the literature published over the past few years, the impacts of these current problems on elephants are increasingly reported. It is through the exposure of the facts that it is possible to promote environmental awareness and, thus, the protection of countless species, such as L. Africana. With this aim, and in order to try to synthesize in a single publication what it was published about this spe- 
cies and the danger it faces, it was carried out a bibliographic review where we emphasize the urgency of protecting elephants and educating people.

\section{Materials and Methods}

To start this bibliographic review, we used the Web of Science (WoS) database and performed a basic search. Through this, we searched for "TOPIC: (Loxodonta africana)" (this option searches for titles, abstracts and keywords that mention the words indicated) and "Timespan: Last 5 years", between July 2015 and December 2019.

Thanks to the results of this literary search, we have analysed the abstracts of 310 articles. Afterward, 149 (that are mentioned here) were selected because they contribute to the main aim of reviewing what have been publicised about the species and what helps its conservation either directly or indirectly. Subsequently, the articles were grouped into different topics (Figure 1): Human-Wildlife Conflict (with 36 articles supporting the topic), poaching (with 30 articles), physical and behavioural characteristics (with 44 articles), the influence of $L$. africana on the landscape (with 20 articles) and its importance in the ecosystem (with 5 articles) and elephants welfare (with 17 articles). It is noted that some articles cover

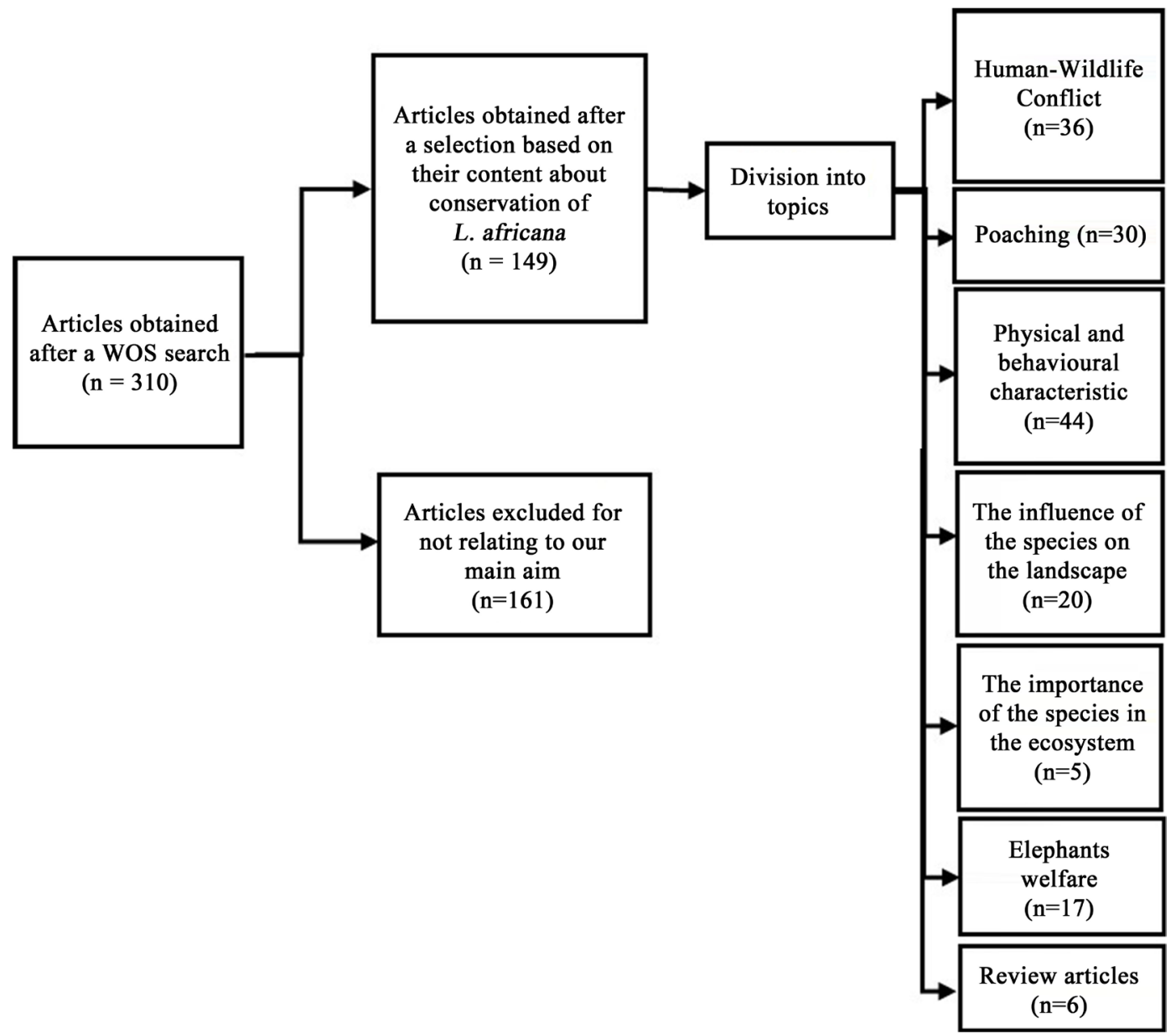

Figure 1. Data flow diagram. 
more than one topic. This literary review also includes 6 bibliographic reviews related to these topics.

The references are in accordance with the ones suggested in the articles tools, except the references of 6 articles (Bastille-Rousseau et al. (2019) [5], Branco et al. (2019) [6], Goldenberg and Wittemyer (2019) [90], Petracca et al. (2019) [2], Schiffmann et al. (2019) [106] and Watson et al. (2019) [110]), that are in accordance with the date of their first publication. Thus, the dates of the articles mentioned here are between July 2015 and December 2019.

\section{Analysis of Content}

The analysis of bibliographic content allowed to organize what has been published in themes, as described in Table 1.

\subsection{Human-Wildlife Conflict (HWC)}

The hard coexistence between humans and elephants is felt nowadays. The complications behind this are also felt in protected areas (PAs) and are especially aggravated in countries characterized by the absence of institutional competence to relieve anthropogenic impacts and with an armed conflict record [2].

Table 1. Description of the themes mentioned in this study.

Theme Description

3.1. Human-Wildlife The anthropogenic impact on elephant populations, conditioning their Conflict (HWC) distribution, behaviour and numbers due to the occupation of the same territory.

Exposition of some traditional strategies used by people to bypass the difficult coexistence of the two species.

The need to do more and better, starting by educating and raising awareness among human populations.

3.2. Poaching: a threat The threat of extinction largely due to poaching and the difficulty of to conservation combating illegal ivory trafficking. The problem of corruption and poverty in African countries and the demand for ivory from East Asia.

The urgency to raise awareness and educate Humankind and the importance of science to combat the poaching.

\subsection{Physical and behavioural characteristics}

3.4. The influence of L. africana on the landscape and its importance in the ecosystem

3.5. The importance of elephant welfare
Description of characteristics that define elephants, such as its cognition, its specific vocalization and the strong dependence on social connections. The need to master this subject for a better application of mitigation strategies.

The contrast of the negative impacts of elephants on certain species and their ecological importance as a key species and ecosystem engineers-the reason why it is urgent to save the species from extinction.

The welfare of elephants as a focal point in ensuring the success of the species. Examples of common diseases or physiological changes that can affect the survival of individuals. 
The Angolan and Mozambican Civil War (1975-2002 and 1977-1992, respectively) represent historical landmarks in the populations of the African savannah elephant, contributing to the devastation of this mammal: however, despite the fact that after these wars the species have shown resilience, including a slight increase in elephant populations (but not enough to guarantee a prosperous future), the inevitable influence of anthropogenic activities was noted, altering the distribution and richness of large mammals [2] [3] [4].

The decline of $L$. africana arises from human pressures stemming from conflict and poaching and the tendency for these pressures to increase is proportional to the need of elephants and humans to share common resources and space [5].

More and more, natural habitats are replaced by cultivated croplands, leading them to be invaded by wildlife that threatens not only human livelihoods, but also their own conservation [6]. The increase of the territorial occupation by human populations and their settlement disturbs the elephant's activities and forces them to create different survival strategies: elephants change their spatial organisation and their activities throughout time [7] [8]. To access crops, this large herbivore learned to be more active at night, when villages are normally quiet, and to run away from these areas during the day, to avoid conflict with humans [8]. Water sources also influence elephant movements in such a way that they move away from protected areas towards rivers [9]. They group together near the same permanent sources of water as humans during the dry period, but they drive away from these sources in wet season [5]. These actions show that African elephants' distribution varies with the season [10] and that they prefer to distance themselves from humans, unless they have no alternative.

In addition to the spatio-temporal change in their activities, elephants are able to adapt their diet to the circumstances. There are researches that record more invasions to crops when there was a lack of resources (as it happens in the dry season) and that adult males are more invasive than females [11] [12]. As herbivores, it is assumed that they prefer the peak of green-up when they are in their natural habitat, but invasive elephants pick mature crops [13], justifying the increase of the invasions in the dry period and adding more damage to the humans.

The invasion of crops and even the destruction of human properties is generally the biggest cause of the conflict between elephants and humans, but the transmission of diseases to livestock and their depredation, as well as threatening the security of human life is also a reality behind the HWC [14]. But not all approaches to crops have the same intention [15] and circumstances that force elephants to do this, do not mean the destruction of crops. Elephants avoid paths associated with humans and use a numerical strategy when forced to approach villagers [16].

From the apparent impossibility of the coexistence of these two species, traditional strategies emerge to relieve tension and to protect human livelihoods. The use of beehive and chilli fences, the combination of these two, guarding of farms, 
electric fences, drones, replacing more attractive cultivations by less attractive ones, hormonal/immunocontractive control of elephants and even lethal control are some of the strategies used to keep the large mammal away from human land-use. However, the efficiency depends on the method that is used.

Beehive fences have proven to be more successful in reducing invasions, however, these have to be placed in strategic locations (key crossing locations) [6] and its length must be considered since the number of invasions tends to decrease in the presence of longer fences [17]. The success of this method does not focus only on the existence of the hive, but on the activity that occurs in it: the set of auditory and olfactory signals, such as the buzzing bee noise and the honey scent, can be more effective in triggering defensive and escape response on elephants [18].

Chilli may be useful to keep elephants away [6], but it will discourage them temporarily; elephants tend to walk away only in the presence of burning chilibriquettes [19]. Thus, the effects of chilli are not usually long lasting and therefore must be combined with other materials, as it happens with sisal string fences soaked in engine oil mixed with ground chili, that are effective in preventing the return of elephants [20].

Guarding strategies are another common method in the defence of properties and it is classified into active or passive guarding (depending if people are present in the field or, not being, are still paying great attention to any noise) combined with other measures: researches in the area has shown that wildlife can damage electric fences to invade crops and that the human noise produced after this invasion, as well as chasing the specimens, tends to cause stress/fear and aggravate the damage caused [21]. Guarding of farms can be more effective if there is detection of the presence of elephants before they invade crops and redirect them to their habitat [21]. The application of electric fences, regardless of their ecological success, could represent a political obstacle, often contributing to the separation and definition of the territory of individuals [22], moving away from its main objective: bypassing the HEC.

Other examples of tactics used include: the presence of drones that disturb the elephants, forcing them to move away from human settlements [23]; the substitution of attractive crops as corn by alternatives crops, such as ginger and lemon grass, may represent an aid to agriculture because elephants consume less of these crops [24]; reproductive control of elephants to avoid overpopulation, male aggression and Human-Elephant Conflict (HEC), as it is referred in the review Somgird and collaborators (2017) [25], such as GnRH vaccination (non-invasive contraceptive method) [26] and vasectomy [27], and lethal control, which is not a viable solution, since in addition to represent a threat to the conservation of the species, the invasion of crops may not always be done by the same elephant [12].

Sharing resources seems to be a trouble sometimes. However, it can bring benefits if we know how to take the opportunities. The different time in which these 
species perform their activities can offer added value to the subject. Throughout History, man has used trees for firewood while elephants used them as food. Most of trees damaged by elephants at night can be collected by humans during the day, thus preventing the interaction between the two species and exemplifies an unrecognized advantage [28].

The appeal of the scientific community for the adoption of effective measures to protect crops against elephants has been growing, in order to combat the conflict and to reduce the invasions of L. africana. In the analysed bibliography, some mitigation strategies are highlighted, such as: the encouragement of local communities to use methods such as beehive fences, that allows humans to benefit from the reduction of invasions and also from the honey production that in turn represents an economic gain [6]; the promotion of budgetary and governmental programs that encourage the use of chilli fences allied with supporting Community-based organizations (CBOs), responsible for the maintenance of ecological buildings [20]; the promotion of the active participation of local stakeholders and government in order to ensure food security and financial stability for the people [29]; the government support regarding to extension services and the link between farmers and extension agents [30]; the adoption of policies that respect both species with the important acceptance and understanding of elephant needs [31]; the prediction of the elephant movements, investing on researches about the behaviour and cognition of these large mammals, in order to prevent conflict and not to remedy it [32]; transboundary cooperation and harmonious programs that focus on the protection and conservation of wildlife and not on other isolationist policies or interests [33] and good land-use planning and creation of buffer zones to define spatial boundaries that avoid conflict [16].

Fortunately, wildlife does not represent a problem for everyone. In fact, many people are able to appreciate every single detail and will to find more about the unfamiliar world. In this regard, the importance of tourism must not be underestimated.

The benefits of tourism to $L$. africana are increasingly notorious: studies reveal a greater number of these species in regions where the number of tourists has increased over the years [34]. Moreover, in a constant struggle for the prosperity of both species, the economic benefits generated by tourism would be well applied if used in favour of farmers who suffer from the damage of their crops created by wildlife [35].

Although there are more reports regarding to crop invasions and the imminent food insecurity, investigating the hidden impacts caused by the large herbivore (such as emotional stress, reduced sense of security and restricted mobility) can be interesting for a better understanding of the negative feelings felt by human populations [36]. The demonstration and explanation of both ecology and elephant behaviour, as it happens in zoological institutions [37], can stimulate awareness of the importance of elephants in the environment and the urgency of their conservation. 
Notwithstanding the significance of the HWC studies analysed here that allow us to verify a constant exposure of the emerging problems, the solutions presented to fight this conflict that harms both elephants and humans are reduced. The extent of the threat that anthropogenic activities pose to elephants (including habitat loss) is in plain view. Promoting traditional strategies should not only be done by the scientific community because the will to live in harmony is (or should be) a feeling shared by elephants and humans. Therefore, the main structures representing each country should bet more on alternatives that enable cohabitation. However, it is known that culture interferes with points of view. We believe that changes must happen "from the inside out": to educate human populations by raising awareness of the species, explaining how to act in its presence to avoid feelings of fear and insecurity. Indeed, enhancing education can be the key to the success of the coexistence of $L$. africana and humans.

\subsection{Poaching: A Threat to Conservation}

Diverse and magnificent forms of life cover the African continent, but the concern must arise when they begin to disappear. As it is mentioned in the review Moolman and collaborators (2019) [38], the decline of the impressive mammal $L$. africana occurs, on a large scale, due to poaching for ivory. This activity represents one of the biggest current problems in the conservation of this species, whose future may be compromised if measures are not taken [3].

Approximately one-third of the remaining number of $L$. africana individuals is found in Botswana, which attributes to this country an essential role in the conservation of the species but, contrary to hopes of overcoming the risk of extinction, there are evidences of a serious increase in the number of elephants lost to poaching in northern Botswana, at least since 2017 [39]. Although a large majority of elephants in Africa live in protected areas, high mortality persecutes the species even in these areas of better safeguarding [40]. The study of demographic changes, using the technique of individual identification [41], can be an aid in understanding the impacts of poaching on elephant populations.

To combat the illegal wildlife trade, it is necessary to understand how and where approaches to the success of this clandestine activity take place. The intensity and location of the poaching can easily be associated with the seasonality, the elephant's population density and the density of waterholes [42].

Forage and water are the main factors that justify the places where many slaughtering occur, because they influence the dispersion of the species. It is common to find elephants near waterholes and it is also here that the number of carcasses increases [43] [44] [45]. Greater poaching activity can also be found near roads (as they facilitate access to wildlife and escape) and in specific types of land cover (whose vegetation generates a wide and open landscape with small shrubs) [44].

In mid-Zambezi Valley (Zimbabwe), in addition to a significant number of elephant poaching hot spots close to protected areas, it was possible to associate 
a greater number of carcasses to the dry season and to places where forage was high [45]. In the Ruaha-Rungwa ecosystem (Tanzania), during the wet season, there was a greater activity of poachers (due to a decrease in rangers' patrolling) at high altitudes (due to a greater dispersion of elephants in this season) [43]. On the other hand, it is in the Laikipia-Samburu ecosystem (Kenya) that the inequalities of poaching are verified spatially and temporally, highlighting the relationship between poaching and the type of land use-unprotected areas, such as private ranching and community areas are a good example of a land use that favours conservation, both in the density of elephants and in the level of poaching [46].

The analyses of poachers' methods are useful to try to identify patterns in their operations, in order to predict their actions so that it can be combated. If poaching strategies do not vary according to different regions, the measures implemented in one place to mitigate attacks can be used in other places. To detect and try to reduce the number of poachers, it is suggested the use of devices that can act at long distances, low cost and with a good night performance, such as drones [44], the promotion of ecotourism and the strengthen ranger coverage overall in areas affected by poaching coupled with aerial devices and the facility development in communal areas [43] [46].

The contribution of poaching to the decline of $L$. africana has already been described here due to the large number of deaths associated with this activity, but the changes that occur in the elephants that survive and in the following generations have not yet been addressed. The extraordinary memory of this species is recognized over time and it can explain the way they react to the fear installed in them throughout a slaughter History [8].

The measurement of the straightness of the path taken by the species is done by tortuosity and varies according to the survival tactics adopted by the individuals; in other words, the ability of elephants to detect the danger that surrounds them, like poaching, can be read in their travel restrictions (they tend to reduce tortuosity (turning less)) and it can be an aid to responsible patrols anti-poaching [47].

Older elephants have larger tusk sizes, which makes them holders of a bigger and more appealing trophy. The selection of these specimens will have consequences for the future generations, as has been proved in an investigation of elephants in southern Kenya [48]: both surviving individuals and those who born after the ivory harvest showed a decrease in tusk circumference at lip and tusk length, especially females, which can be justified by the greater tendency to seek large tusks in groups of elephants (usually related to females). This phenotypic change is based on genetic changes and the possibility of the disappearance of the ivory bearing gene can cause difficulties for the defence and feeding, but it can also represent hope for the future of the species [49]. The preference for older individuals, in addition to influencing the future phenotype of the species, could trigger problems in the social and hierarchical structure present in elephants. However, the powerful network whereby these species live has demon- 
strated resilience to the pressures caused by poaching, often with survivors correcting the failures caused in their social structure and with younger generations (daughters) taking up positions of their lost ancestry (mothers) [50].

The low number of individuals per population found in South Africa's reserves, caused by several reasons, being poaching one of them, can mean that elephants are not genetically viable [51]. This genetic problem can be avoid with crosses between different populations and this might be achieved through wildlife corridors, which serve to facilitate circulation and to extend habitat [52] and can allow a greater sighting of elephants [53].

The pressure of poaching, long migrations or even climatic variations can give rise to isolated populations that are forced to change behaviours to survive. Genetic changes could contribute to new adaptations but, in the Namib Desert, it was discovered that the elephants' great ability to learn allowed them to change their ranges and to survive in a harsh environment [54].

In addition to associating the researches in the field of conservation genetics of $L$. africana with the existence of long-term conservation projects as measured by the literacy rate in a country, the review Zacarias and collaborators (2016) [55] observed that a large part of the samples collected in the analysed researches came from Tanzania, Kenya and South Africa. Thus, it suggests that research in this field should also be started in other countries hosting L. africana populations, increasing the contribution to the knowledge and understanding how the populations are structured and how the genetic differentiation helped this mammal dealing with challenges associated with conservation, like poaching.

The incongruity behind some genetic analysis of the savannah elephant ( $L$. africana) and the forest elephant (L.cyclotis) leads to the emergence of hypotheses like the possibility of occur (fertile) hybridization between these two species [56]. Data collected in the border of the Democratic Republic of Congo and Uganda, Central African Republic, Garamba region and Pendjari-Arli complex of West Africa demonstrated the existence of hybrid zones and the existence of crossings over generations, reinforcing the idea that hybrids can be fertile-once again, poaching and habitat loss may be behind these changes [57].

The high frequency which ivory hunting occurs can be harmful to trophy hunting, since the marked loss of elephants with the desired characteristics influences the scoring system used in this practice [58].

The beauty of ivory enriches several artistic works, but it is the price associated with it that attracts more and more poachers, especially when the demand grows and the supply does not keep up with it [49]. The strong contribution to the conservation of $L$. africana comes from Southern African countries and this may not be enough to combat the demand for ivory from the far East Asia [34]. The main Chinese markets stand out as protagonists and their ivory demand influence African countries in different ways, depending on the level of poverty and corruption associated with each country-it is urgent to deal with these two factors for greater success in combating poaching [59]. The rational exploitation 
of a limited resource, independently and to satisfy individual interests, even against the best for others, has a name: the tragedy of the commons. Even with the boundaries imposed on international ivory trade by The Convention on International Trade in Endangered Species of Flora and Fauna (CITES), this continues to happen at a rapid pace and the inability to preserve the threatened species is associated with economic and cultural issues-taking into account the social context in which each person lives, it is important to raise awareness among human populations with conservationist causes; according to Jung (2017) [60], two proposals to combat the tragedy of the commons may involve government control over resource management and a decentralized ownership, in which case resources are regulated by a private enterprise or the community.

The poisoning of wild animals, often through contamination of the waters, leads to a silent death, diverting attention. Associated with death, vultures are birds that could easily denounce poachers and the location of a slaughter and that is why the poisoning of vultures or elephant carcasses has gained strength; so far, poaching has shown good work outside the law and the use of poisons demonstrates, once again, the (illegal) success of poachers, wherefore African governments may need help to enforce the law, which could come from international support [61]. It is believed that strengthening law enforcement in poaching hot spots on the African continent could prevent massive loss of specimens, and if conservation measures are targeted at the main slaughter sites (avoiding random lookouts), the results could be more promising [44] [62].

Science represents a strong ally in trafficking control, being very useful in tracing the origin of ivory [49]. Through multiplex PCR-electrophoresis assays, the origin of the ivory can be proven, ignoring the chances of it being false and allowing the potential traffickers to be penalized according to the severity of the conservation status of the species in question [63]. On regional scales, the efficiency of isotopic profiling of African elephant ivory has already been demonstrated, but it is normal that some variations might be observed within the sampling locations and the individuals studied, so strengthening research in this area and in sampling methodology is essential [64].

Poaching is a major threat to wildlife and $L$. africana does not shy away from this. It generates a highly profitable business and poachers, in general, dedicate themselves to this job by necessity and the ease of making money (even if they do not earn big profits), ending up not knowing the real dimension of this trade. Dealing with the demand for ivory and the corruption and poverty of African countries is urgent to save $L$. africana from extinction. The human being tends to be aware of the damage caused when it is too late. Since prevention is always better than cure, we believe that this front can and must also be confronted: awareness and once again education. No human being should forget that we are part of an ecosystem and that conservation and balance are everyone's duty. It is essential to understand the role of each living being on the planet so that we never pass over other species until their extinction. 


\subsection{Physical and Behavioural Characteristics}

It should be noted that the attention of the authors analysed here, over the years, has focused on the physical and behavioural characteristics of elephants. As already mentioned, elephant responses to the surrounding environment may well define the success of the species and their awareness can contribute to better mitigation strategies.

To study any animal, it is necessary to understand what moves them and, in general, food and water are the main reasons. A study carried out in Atherstone Collaborative Nature Reserve in South Africa has shown that this herbivorous species, despite being able to feed on different parts of plants, has a preference for tree bark, branches and leaves, with a greater consumption of the first two when the drought arrives [65]. In a study at Ithala Game Reserve, in South Africa, the foraging decisions were tried to be understood-the type of soil may be a factor that justifies them, especially in the dry season; it was also verified a greater interest by elephants in trees with higher concentrations of protein [66]. Terrain ruggedness and slope can also be crucial factors that justify the movement of elephants and it is important to bear in mind that it is not only the seasons that can change the species' behaviour (during the day this can also happen); forecasting elephant routes can also be useful in defining tourist routes [67].

Males and females may have differences in their methodology for picking food according to their needs: in Clegg and O'Connor (2016) [68] it was described that males spend more time on harvesting and handling (from harvesting food to swallowing it) than females.

In the Miombo ecosystem of the Ugalla Game Reserve it was detected that elephants practised geophagy (from certain termite mounds); such behaviour can be explained by the richness in mineral elements found there [69]. The role of geophagic termite mounds can be so important in feeding elephants that it can influence their movement in Ugalla.

The distance from rivers (or other sources of water) is also one of the greatest influences of displacement and the establishment of large herbivores [70]. Many times, to overcome the distance of water sources, its low flow and poor quality (for example, contamination), $L$. africana digs as an adaptive strategy to access this fundamental resource [71].

Artificial waterholes can be provided to help wildlife combat drought, but this practice generates debates with pros and cons; a study of the impacts of these artificial sources in the Kruger National Park showed that the spatial utilisation patterns of elephants have been altered, which may have contributed to an increase in the use of certain areas and further suggests that their removal may prevent these variations, favouring the conservation of species [72].

The reasons why elephants move can also influence the speed at which they walk. When faced with a more fragmented and less productive landscape, elephants tend to increase their speed of passage [73], since less amount of forage does not justify their establishment. Although there are great reasons that may 
justify migrations of elephant populations, they are considered facultative partially migrants: not all individuals in a population migrate and those who do may not even do it every year, but only when it is more opportune [74]. Therefore, migratory behaviour is a peculiar characteristic of each individual.

Due to these travels and the impact that their large size/body mass can have on their feet, the elephants' movement may have certain characteristics-first, they tend to step on the side of the foot and then transfer this pressure until toe-off-but this way of walking may depend on the elephants, which can be associated with causes such as husbandry and the environment where they grow [75].

The activity of these species is well studied but knowing their inactivity and hours of rest can also be important for a more detailed knowledge of the species. At a private reserve in the Western Cape, South Africa, a study was conducted on captive elephants where it was found that they also yawn and that this behaviour may be associated with stimulation from nighttime recumbencies [76]. Despite having this characteristic common to most mammals, a study in the natural habitat of two matriarchs showed that the African elephant has the shortest sleep time recorded within this large group and, even when they spent a sleepless night, they showed no need for recover hours of sleep; it was also possible to discover that these animals are polyphasic sleepers and that they express recumbent and standing sleep [77]. This state of the elephants may be associated with poaching or predation pressures [77] and so far the result of the human-wildlife conflict can be seen, with elephants showing behavioural changes in their resting phases, deviating from areas where human presence is noted [78].

Among the many characteristics of elephants, cognitive ability and memory are probably the ones that most attract and fascinate researchers. These species can collect and store information about the landscape over space and time [79], like knowing where different sources of water are located [80]. They may also be able to distinguish the threats that surround them, as seen in northern Kenya, in a study of an endangered elephant population: even traumatized by poaching, elephants did not demonstrate defensive behaviour in the presence of (harmless) humans, suggesting that they can differentiate the intentions of people [81]. However, human pressures can cause stress and consequent aggressiveness, so the behaviour of elephants must be monitored to ensure the well-being of both species, especially in tourist moments [82] or investigations that require interactions.

Smell is an essential sense for the daily routine of elephants, as well as for their protection: elephants have already demonstrated their ability to detect trinitrotoluene (TNT) (a component commonly used in mines), which gives strength to anecdotal reports that argue that $L$. africana avoided minefields at a time when war dominated Angola [83]. However, it is not only essential for their protection, but also for foraging. This sense is so developed in elephants that they are able to detect their favourite plants, even with olfactory interferences, such as the presence of volatile organic compounds in the environment [84]. 
Behavioural adjustments are crucial for the balance of the species, as it can be seen in their contribution to obtaining homeothermy. When high temperatures reach Africa, it is behavioural changes, such as wetting behaviour, shade use and changes in walking, food and rest that guarantee thermoregulation-this need for certain resources must have been taken into account in future conservation measures [85].

Attention to behavioural changes must be strict because it can be an asset for mitigation strategies. Infrasonic vocalization and even locomotion represents the signature of each individual and, on a more comprehensive scale considering the similarities, it can represent the signature of the species under discussion. The terrestrial vibrations produced by elephants can provide a "seismic signature" which, through seismological techniques, can be monitored, distinguished from a distance and classify the specific behaviour of elephants [86]. If we can read and understand the behavioural changes of elephants, we may be able to intervene when threats (such as poaching) appear.

The exploitation of resources is due to cultural behaviour learned over the generations and the establishment of populations in characteristic locations is not based on the abundance of resources associated with this habitat, but rather on the family tradition to remain in their typical habitat [87]. Even though the teaching is a constant sharing within each group of elephants, it is important to consider the potential that differences between individuals have to characterize the structure of a population (taking into account the individual behaviour of each elephant) [88]. It is the knowledge of these structures and the factors that influence them that will allow conservationists to act to protect the species.

McKnight (2015) [89] devoted himself to studying the relationship between the distribution of elephants in Tsavo East National Park and the dynamics of the group in which they live, where he demonstrated that groups of males and mixed groups were located in the dry and wet season, but in relation to solitary males, this was only possible in the wet season, since they are distributed more in the dry season, as well as family units.

The Goldenberg and Wittemyer (2019) [90] review highlights the behaviour of these individuals towards their dead. Touch and certain approaches to carcasses, regardless of the state of decomposition, as well as visiting carcasses and demonstrating extensive investigative behaviour, temporal gland streaming, selfdirected behaviour and intense social interactions among the living near carcasses prove the interest that elephants have in their deceased members and the strength of these social groups.

Musth is a state in which males enter due to increased hormonal production. This results in an increase of aggressiveness and other behavioural changes to find female in estrous cycle. This state can be reached at any time when the males are sexually mature and it provides them advantages during the mating season: normally, moments of aggressive interactions are overcome by larger bulls, but smaller musth bulls can overcome larger non-musth bulls, in addition to the fact 
that estrous females tend to prefer males at this stage-a game-theoretic model based on this aggressive behaviour was developed and already managed to predict, over space and time, how musth males are distributed [91].

However, reproductive success does not depend only on hormonal production -social behaviour has a considerable influence on this process, as well as on survival: orphaned females tend to relate more with age mates and non-dominant specimens and less with mature adults; this can impair access to resources and impair fitness [92]. The influence of social bonds in this species is so strong that its understanding is imperative to apply conservation strategies, such as translocations [93], where the social role can be a decisive factor in the result of this process. Thus, events in the social life of elephants contribute to their quality of life [94].

Social and sexual communication between individuals is greatly influenced by the specific acoustic characteristics of $L$. africana. As happens in humans, the difference between genders causes differences in vocalization. Through the rumbles (low-frequency calls), it is possible to identify the sex of the vocalizing elephant; characteristics like vocal tract resonant frequencies are associated with the size of the individual, but the sexual differences detected in the social rumbles are not entirely related to the sexual size dimorphism [95]. It is not only the distinction of gender that is possible through acoustic signals; female elephants recognize individuals and their relatives through vocalization and produce specific sounds (like loudspeaker) only in the presence of individuals whom they share strong ties [96]. In turn, males are also able to do this identification, but the response to the situation is different: instead of connecting more with familiar voices, they tend to move away from them and move towards unknown females-this behaviour can happen with the aim to prevent inbreeding [96].

Although males tend to be more lonely during the mating season, non-musth males can also exhibit a social structure like females, based on hierarchies and companionship; males rumbles allow the recognition of age, size and individuality and understand this functional relevance is essential to understand communication between males and between males and females [97].

Acoustic communication is a common feature of the three extant elephant species (L. africana, L. cyclotis and Elephas maximus) and can arise in the form of combined calls. However, knowing that these combinations are different between the three species, it remains to be seen whether this is due to socioecological factors or phylogenetic relationships: Pardo and collaborators (2019) [98] demonstrated that roar-rumble combinations are mostly produced by $L$. africana and E. maximus, while L. cyclotis was associated with different combinations; in this research, it was also detected that the favoured structure of the combinations can differ significantly between populations of the same species and that specific contexts can trigger certain acoustic signals (not so common). Thus, Pardo and collaborators (2019) [98] concluded that the phylogenetic history of these species is not the main cause of the differences in the combined calls, but rather the socioecological conditions of the places. 
A considerable number of the bibliography used reported experiences/research done in zoos. Nowadays, zoos raise several social issues regarding their usefulness/functionality. The debates on this theme focus mainly on two questions: are zoos just a source of financial income for which is necessary to sacrifice the freedom of animals or are they conservation units with the capacity to prevent the extinction of species? Regardless of the individual position of each one, zoos are a reality these days and it is up to their managers to certify the well-being of each living being that inhabits there, so searches related to the behaviour of elephants are necessary to guarantee the future of the species, like it happens in the wild.

Factors such as presence of calves in the herd, age and relatedness to other elephants in the herd (unrelated/related elephants) influence social interactions and, consequently, herd compatibility; in Williams and collaborators (2019) [99], calves demonstrated more positive interactions than adults, the presence of calves in the herds was associated with more positive interactions and the presence of relatives in the groups (compared to unrelated elephants) was also associated with more positive interactions. In addition, more social elephants indicate more positive interactions with other elephants: the influence that the personality of each individual has on connections with others reflects the importance of further evaluations in this area to enhance the formation of successful social groups in zoos [100]. These positive interactions can also be seen in play behaviour (like play bout) [101]. Thus, several indicators of well-being depend on social and management factors [102]. A study conducted in 68 North American zoos showed that elephants' social interactions are greatest during the day; it also demonstrated that they spend more time outdoors than indoors and that the time spent on hard flooring is variable, being longer at night [103].

Just as they recognize each other, elephants raised in zoos recognize their keepers and this relationship (human-animal relationship (HAR)) influences the welfare of elephants; however, interactions with non-family keepers may have no detrimental effects on elephants, which provides a reason to potentiate this type of interactions, improving HAR [104].

The environment where elephants live also influences their well-being and this should not be overlooked where elephant breeding takes place, as it happens in zoos. The quality of the recumbent rest of these species is dependent on the quality of the flooring substrate [105]. An example is the fact that the nocturnal resting behaviour of elephants was improved when a breeding group of elephants was exposed to sand flooring, which may be an incentive for the installation of mounds of sand and horizontal structures in breeding facilities to improve resting behaviour [106]. Thus, observing the behaviour of elephants in zoos allows the managers to meet the needs of elephants, such as renovating the floors to promote the well-being of this mammal [107]. To identify the elephants' body orientation (as a sleep indicator) and their activity levels, Soltis and collaborators (2016) [108] demonstrates the usefulness of accelerometers on elephant collars. 
Most of the articles reviewed here focus on studies of the behaviour of elephants (either in the wild or in captivity). This section exposes a diversity of characteristics of these species, from the influences on their distribution and on their resting behaviour, to their olfactory and cognitive abilities. Knowing every detail of this species is essential to understand its needs and to predict its behaviour. In this way, it is possible to avoid disturbances in the environment where elephants live, improve mitigation strategies and enhance the species' recovery.

\subsection{The Influence of $L$. africana on the Landscape and Its Importance in the Ecosystem}

The distribution of elephants is directly associated with the productivity of the landscape and its fragmentation. Elephants prefer landscapes with intermediate productivity and less fragmentation [73] [109]. But, although elephants depend on the landscape around them, they are constantly accused of altering the landscape and harming some species, especially trees.

High elephant densities are associated with high mortality rates of Senegalia nigrescens (typically ring-barked by elephant) and the protection of this species may include the presence of clusters of Hyphaene petersiana [110]. High elephant pressure causes the isolation of Borassus aethiopum adults (which can have direct consequences on pollination) and reduces their density [111], as well as restricts the species' functional diversity [112]. Analyses carried out in the Nazinga Game Ranch (Burkina Faso) associated considerable changes in the abundance of species (such as Maytenus senegalensis, Acacia gourmaensis and Vitellaria paradoxa) with elephant browsing [113]. In Mana Pools National Park (Zimbabwe), baobabs trees (Adansonia digitata) showed more damage and disturbances in their abundance and structure (height and basal area) when they were closer to water sources [114] - the establishment of elephants occurs largely near these ones. Marula trees (Sclerocarya birrea) are also examples of trees that have their decline associated with elephants, especially due to the high predation of their seeds and seedlings [115]. Thus, and according to Mograbi and collaborators (2017) [116], elephants, together with human presence, may be the most influential variables in the fall of trees and in the tree seedling survival, which can affect the sustainability of woodlands. In addition to affecting the density of trees, Tripathi and collaborators (2019) [117] demonstrated that the African elephant affects the richness of bird species, which can cause the spatial homogeneity of these ones.

A study performed based in the components of Albany thicket vegetation (South Africa) demonstrated that $L$. africana was responsible for change the structure of the vegetation, although the impact of this species does not have to be negative, if the density of elephants and the occupation time of a given space are reduced [118].

In Gorongosa National Park, over 35 years, there was a woodland expansion after the disappearance of large mammalian herbivores, resulting from the Civil 
War [119]. On the other hand, in Northern Botswana, Fox and collaborators (2017) [120] observed little evidences that supported the idea that unsustainable pressure on woodlands is related to the increase in the number of elephants, although this is one of the main commonly cited causes that justify woodland degradation; however, there was an indication that Land Cover Change (LCC) processes, in semi-arid savannas, may be associated with anthropogenic and environmental causes.

The impact of L. africana on forest degradation can be superficial when compared to other factors, so its presence does not need to be constantly considered negative [121]. In contrast to the negative impacts caused by elephants on greater height plants, it is necessary to emphasize the benefit they can bring. Understory plants benefit from the presence and movements of this large mammal-the damage caused to tree canopies (e.g. fallen branches) may be associated with the creation of refuges for small plants, inhibiting their consumption by other animals, contributing to the increase in species richness and in the biomass of this type of plants [122].

Changes in the number of elephants can cause cascading community effects, since the presence of this species influences the herbivore community-for example, megagrazers have already demonstrated positive responses associated with the impact of elephants on trees, unlike mesobrowsers, which did not appear benefit from this [123]. The herbivore community is a mouldable structure when changes occur in the density of the key species of the ecosystem, in this case, $L$. africana.

Elephant populations and the beautiful undegraded landscapes are always important factors of attractiveness, especially for tourism. Residents and tourists in the Associated Private Nature Reserves (South Africa) demonstrated to be more favourable to strategies that involve managing ecosystem functioning than controlling elephant populations [124].

The restoration of the environment must always be carefully considered. Interference in ecological processes may be necessary but in effective cases of degradation of the landscape; conservation strategies should consider protecting large trees, but never forgetting ethical approaches to elephant populations [125].

Contrary to some environmental management strategies (such as environmental manipulation, translocations, slaughter and use of contraceptives to reduce the number of elephants), Derham and collaborators (2016) [126] suggests the direct protection of trees, using wire netting.

The increase of the number of elephants in certain regions, such as natural protected areas, often stems from combating the extinction of the megafauna. Unsustainability is generated by exaggeration. The fall of large trees due to the behaviour of elephants is worrying when it happens in exaggeration. The confinement of elephants in an attempt to protect the species affects the functioning of the ecosystem, so conservation strategies must adjust to these two relevant factors [127]. 
The predominance of an exposure of the negative impacts of elephants noted throughout this review, labels these animals as a problem for several species. Its importance in the ecosystem is merely addressed, although it is one of the most relevant points when one wants to sensitize others to the need to protect and save $L$. africana from extinction.

Elephant footprints can be important for signalling their presence or for research that tries to correlate their depth and size with the sex, age and size of the specimen [128]. What can often go unnoticed is what these footprints may contain inside-they accumulate water and make it possible for other living beings from the group of Dytiscidae and Hydrophilidae to colonize them, which makes them a highly diverse habitat for several individuals and that provides dispersion [129].

The negative impacts of this specie's diet have already been highlighted here, but the other side remains to be addressed. Of the consequence of its feeding, it stands out the ability of $L$. africana to disperse seeds of large-fruited trees, suggested in Bunney and collaborators (2017) [130] as "the longest distance terrestrial vertebrate disperser investigated". The dung of this species can also serve as protection for tree seeds, like it happens with Tamarindus indica, resulting in seeds with less levels of beetle infestation and removal (e.g. by seed predation), and can represent a mean of protection for post-dispersion seeds [131]. Elephant dung has a composition rich in phosphorus, nitrogen, carbon and potassium, reinforcing the beneficial role of these species in the functioning of the forest ecosystem [132].

Thus, $L$. africana is positioned as a key species in the dynamics of African ecosystems [129], and they are also considered ecosystem engineers [132] for all their performance: they modify the habitats, disperse seeds contributing to the conservation of the diversity of certain species of trees, create habitats for small species along their walks and even produce dung that can bring benefits to the environment. Although the references that raise the importance of the species in the ecosystem are limited, those addressed here should be more than sufficient to prove that, in fact, the species has a crucial role in its natural habitat. Even referred to as a problem for some, for others it can be the solution and the support to guarantee a future. For the reasons shown here and more, $L$. africana must be urgently protected and removed from the danger of extinction.

\subsection{The Importance of Elephant Welfare}

The guarantee of the welfare of an animal depends on the knowledge of its state of health (either physical or mental). In this section, it's addressed the points mentioned in the articles analysed that focus on identifying health problems in L. africana. This study area promotes the restoration and future maintenance of this mammal's health, to ensure the survival of the species.

The age and sex of elephants can be associated with clinical events, as well as extrinsic factors, such as housing and management [133], which make it neces- 
sary to monitor the welfare of elephants, especially when they are raised in captivity, so that it is possible to circumvent existential problems. Thus, the environmental factors of zoos can be linked to the health of individuals.

A study carried out in zoos in North America used, as an indication of stress, the mean concentration and individual variability of faecal glucocorticoid metabolite concentrations (FGM) and demonstrated that zoo elephants located in northern latitudes had higher concentrations of FGM and that these concentrations can be influenced by free access to different spaces, as well as the possibility of interacting (or not) socially [134]. This indicator of physiological stress can also be useful in detecting other problems, as in assessing the impact of anthropogenic activities on the health of elephants: in Hunninck and collaborators (2017) [135], higher concentrations of FGM were detected in dung samples from elephants that lived outside Etosha National Park, indicating that unprotected areas have more stressful effects on elephants, possibly because of human disturbances.

The temporal gland secretion physiological marker (TGS), in males, may be associated with the musth period and, in females, essentially associated with excitement (for example, the feeling of meeting a group that has been separated) and distress: the probability of TGS seems to be higher with age, in addition to being more prone in females, except when they are in large groups, contrary to what happens with males [136]. This physiological analysis highlights the importance of maintaining social systems in elephants.

In Hartley and Stanley (2016) [137], maternal and allomothering experience, herd compatibility and stability and management at parturition proved to be the most decisive factors in the reproductive success of African elephants in captivity and that endotheliotropic herpes virus is strongly responsible for calf mortality. Added to this, the presence of mothers can contribute to the reproductive rate of their daughters, highlighting, once again, the importance of family bonds in these social groups and the protection of older individuals, even if they are no longer in their fertility period [138].

Regular monitoring of the hormonal status of elephants can be facilitated when they are raised in captivity. Chave and collaborators (2019) [139] associated musth with hormonal changes, more specifically with the levels of cortisol, LH, testosterone and thyroid hormones and considers that this condition on males can be a metabolic challenge; however, variations in parameters between individuals make it difficult to create a general endocrine profile, which highlights the importance of monitoring this hormonal status from an early age. In females, hormonal problems can also be associated with captive breeding, such as hyperprolactinemia and ovarian acyclicity (reproductive problems): through an analysis of prolactin and serum progestogens, Brown and collaborators (2016) [140] demonstrated that, in 95 females raised in zoo environment, more than half presented acyclicity or irregular cycling; also pointed out that increases in feeding and enrichment diversity and social stability can have a positive impact 
on the hormonal levels of the species. The hypothesis that oxytocin and serotonin concentrations are increased in non-cycling, hyperprolactinaemic elephants is analysed in Prado and collaborators (2019) [141], where the authors conclude that dopamine synthesis may not be impaired in these elephants and that certain stimulating factors may be behind hyperprolactinemia.

Acyclicity and potentially heart disease may be associated with obesity, as a consequence of a lack of adequate exercise [142]. In Morfeld and collaborators (2016) [143], a group of zoo elephants were evaluated, suggesting that the number of obese elephants in captivity may be greater than expected in Nature and that long walks and unpredictable feeding times may contribute to a decrease in obesity.

The musculoskeletal and foot conditions of elephants living in zoos are increasingly documented, with records of direct associations between age and foot health and, most notably, musculoskeletal disorders associated with space experienced in indoor/outdoor exhibits and time spent on hard substrates [144]. Thus, and as previously mentioned, renovations of the floors in the zoos can relieve the stress caused to elephants and also prevent common pathologies, such as foot arthritis [107].

Tuberculosis (TB) is a disease caused by the infection of Mycobacterium tuberculosis, which has been affecting $L$. africana. Kerr and collaborators (2019) [145] used two serological tests to detect TB antibodies, leading to the conclusion that TB seroprevalence is higher in males than in females and higher in adults, compared to younger elephants ( $\leq 24 \mathrm{yr})$. Here, the authors emphasize the need for more retrospective studies to assess the risk of this disease, especially in wild populations.

The haematological changes associated with inflammation in elephants have been vaguely documented; in Stacy and collaborators (2017) [146], qualitative morphological changes in $L$. africana leucocytes, which include reactive lymphocytes, plasma cells and/or vacuolated monocytes, are described. Timely detection of these changes may provide relevant information of the health status of these animals.

Problems in elephant dentition can have serious consequences for elephant well-being, and a thorough knowledge of this subject is necessary to maintain healthy populations. The storage of mammalian jaws, including elephants, is a common practice that provides important evidence and information about individuals and populations. Growth of molars (bony growths and alveolar abscesses) are examples of health problems of veterinary interest reported in Parker (2017) [147], associated with nutritional deficiency, which can serve as an alert for the state of health and well-being of populations. Tusk fractures, also an example of a health problem associated with dentition, can lead to pulpitis; Sim and collaborators (2017) [148] describes the advantage of using composite materials to control these fractures and also mentions the usefulness of endodontic therapy in the treatment of the problem. 
In the bibliography studied here, the percentage of articles related to this section is reduced. However, we reinforce the importance of a greater dedication and research in the veterinary area, for a better protection of the species. As well as quantity, quality is also a decisive factor in the conservation of $L$. africana and it is through the knowledge of the common pathologies in this species and its state of health that the objective can be achieved.

\section{Discussion and conclusions}

In the Nichols and collaborators (2017) [149] review it was suggested that research in the forest sector, rather than focusing on fires and elephants, should prioritise other types of threats. Contrary to this, and never ignoring the importance of research in other fields, we enhance the need of more searches related to elephants, especially $L$. africana, due to all the factors exposed here.

Several authors analysed in this study have focused on the behaviour of elephants. This section covers several articles that expose common habits of the species, whose report is crucial for the implementation of mitigation strategies. In addition, the exposure of common problems affecting the health of elephants also plays an important role in the conservation of the species. The mastery of this area allows elephants to recover from certain diseases, with the veterinary medicine help. Data collected from animals raised in captivity were frequent in the articles addressed in these two sections.

In the Fritz (2017) [150] review it was indicated that long-term-field studies tend to highlight the spatial dynamics of populations in response to anthropogenic/climatic changes and the effects of these ecosystem engineers on landscapes, other species and ecosystems. In our review, we observed, with some frequency, reports of elephant movements on a spatial and temporal scale. But, the importance of this mammal in ecosystems was poorly mentioned, so we highlight the need for further research in this field, to demonstrate to the need and urgency to preserve this species. On the other hand, we observed greater attention to the impact caused by elephants on vegetation.

It is notable that certain sections, such as HWC and poaching, have greater bibliographic support. This is probably due to the fact that these sections are the main conditioning factors in the conservation of the species. However, despite the abundant amount of information that can be found about this, we feel that too little efforts are being done. We believe that the failure does not come from the scientific community that, over the years, has intensified investigations and warnings about the danger of the consequences that are coming, if measures are not taken.

Programs that support the financial security and food stability of human populations are essential to combat the decline of $L$. africana. However, if the guarantee of law enforcement can be complicated, if corruption and poverty interfere with the protection of the species, if humans can pose a threat to this terrestrial mammal, thus, Humanity has the duty and the power to circumvent the 
negative impacts that have caused on this mammal. For this reason, we defend the need to raise awareness and educate human populations, especially those who see $L$. africana as a plague or those who see poaching as a source of income.

Although with some discrepancies in the bibliographic quantity that supports each section, we conclude that the publications made about the species, over the time studied here, are essential to providing a collection of significant information that allows correct choices regarding mitigation strategies and the management of elephant populations, thus strengthening conservation measures and safeguarding a future for Loxodonta africana.

\section{Conflicts of Interest}

The authors declare no conflicts of interest regarding the publication of this paper.

\section{References}

[1] Blanc, J. (2008) Loxodonta africana. 2008 IUCN Red List of Threatened Species. Gland, Switzerland, 8235. http://www.iucnredlist.org

[2] Petracca, L.S., Funston, P.J., Henschel, P., Cohen, J.B., Maclennan, S. and Frair, J.L. (2019) Modeling Community Occupancy from Line Transect Data: A Case Study with Large Mammals in Post-War Angola. Animal Conservation, 1-14. https://doi.org/10.1111/acv.12555

[3] Schlossberg, S., Chase, M.J. and Griffin, C.R. (2018) Poaching and Human Encroachment Reverse Recovery of African Savannah Elephants in South-East Angola Despite 14 Years of Peace. PLoS ONE, 13, e0193469. https://doi.org/10.1371/journal.pone.0193469

[4] Stalmans, M.E., Massad, T.J., Peel, M.J.S., Tarnita, C.E. and Pringle, R.M. (2019) War-Induced Collapse and Asymmetric Recovery of Large-Mammal Populations in Gorongosa National Park, Mozambique. PLoS ONE, 14, e0212864. https://doi.org/10.1371/journal.pone.0212864

[5] Bastille-Rousseau, G., Wall, J., Douglas-Hamilton, I., Lesowapir, B., Loloju, B., Mwangi, N. and Wittemyer, G. (2019) Landscape-Scale Habitat Response of African Elephants Shows Strong Selection for Foraging Opportunities in a Human Dominated Ecosystem. Ecography, 43, 149-160. https://doi.org/10.1111/ecog.04240

[6] Branco, P.S., Merkle, J.A., Pringle, R.M., King, L., Tindall, T., Stalmans, M. and Long, R.A. (2019) An Experimental Test of Community-Based Strategies for Mitigating Human-Wildlife Conflict around Protected Areas. Conservation Letters, 13, e12679. https://doi.org/10.1111/conl.12679

[7] Mpakairi, K.S., Ndaimani, H., Kuvawoga, P.T. and Madiri, H.T. (2019) Human Settlement Drives African Elephant (Loxodonta africana) Movement in the Sebungwe Region, Zimbabwe. African Journal of Ecology, 57, 531-538. https://doi.org/10.1111/aje.12639

[8] Gaynor, K.M., Branco, P.S., Long, R.A., Gonçalves, D.D., Granli, P.K. and Poole, J.H. (2018) Effects of Human Settlement and Roads on Diel Activity Patterns of Elephants (Loxodonta africana). African Journal of Ecology, 56, 872-881. https://doi.org/10.1111/aje.12552

[9] Youldon, D.A., Abell, J., Briffitt, J.S., Chama, L., Channings, M.D., Kilundo, A., 
Larsen, C.K., Sakala, D. and Schulte, B.A. (2017) Patch-Occupancy Survey of Elephant (Loxodonta africana) Surrounding Livingstone, Zambia. Koedoe, 59, a1372. https://doi.org/10.4102/koedoe.v59i1.1372

[10] Buchholtz, E., Fitzgerald, L., Songhurst, A., McCulloch, G. and Stronza, A. (2019) Overlapping Landscape Utilization by Elephants and People in the Western Okavango Panhandle: Implications for Conflict and Conservation. Landscape Ecology, 34, 1411-1423. https://doi.org/10.1007/s10980-019-00856-1

[11] Cook, R.M., Henley, M.D. and Parrini, F. (2015) Elephant Movement Patterns in Relation to Human Inhabitants in and around the Great Limpopo Transfrontier Park. Koedoe, 57, a1298. https://doi.org/10.4102/koedoe.v57i1.1298

[12] Smit, J., Pozo, R.A., Cusack, J.J., Nowak, K. and Jones, T. (2019) Using Camera Traps to Study the Age-Sex Structure and Behaviour of Crop-Using Elephants Loxodonta africana in Udzungwa Mountains National Park, Tanzania. Oryx, 53, 368-376. https://doi.org/10.1017/S0030605317000345

[13] Branco, P.S., Merkle, J.A., Pringle, R.M., Pansu, J., Potter, A.B., Reynolds, A., Stalmans, M. and Long, R.A. (2019) Determinants of Elephant Foraging Behaviour in a Coupled Human-Natural System: Is Brown the New Green? Journal of Animal Ecology, 88, 780-792. https://doi.org/10.1111/1365-2656.12971

[14] Matseketsa, G., Muboko, N., Gandiwa, E., Kombora, D.M. and Chibememe, G. (2019) An Assessment of Human-Wildlife Conflicts in Local Communities Bordering the Western Part of Save Valley Conservancy, Zimbabwe. Global Ecology and Conservation, 20, e00737. https://doi.org/10.1016/j.gecco.2019.e00737

[15] Wilkie, R.D. and Douglas-Hamilton, I. (2018) High-Resolution Tracking Technology Reveals Distinct Patterns in Nocturnal Crop Raiding Behaviour of an African Elephant (Loxodonta africana) in Amboseli, Kenya. Pachyderm, No. 59, 41-48. https://www.savetheelephants.org/wp-content/uploads/2020/02/2018 Wilkie etal High-resolutionTrackingTechnologyRevealsDistinctPatternsInNocturnalCropRaidi ngBehaviourOfEle 8pages.pdf

[16] Songhurst, A., McCulloch, G. and Coulson, T. (2016) Finding Pathways to HumanElephant Coexistence: A Risky Business. Oryx, 50, 713-720. https://doi.org/10.1017/S0030605315000344

[17] Scheijen, C.P.J., Richards, S.A., Smit, J., Jones, T. and Nowak, K. (2019) Efficacy of Beehive Fences as Barriers to African Elephants: A Case Study in Tanzania. Oryx, 53, 92-99. https://doi.org/10.1017/S0030605317001727

[18] Ndlovu, M., Devereux, E., Chieffe, M., Asklof, K. and Russo, A. (2016) Responses of African Elephants towards a Bee Threat: Its Application in Mitigating Human-Elephant Conflict. South African Journal of Science, 112, 1-5. https://doi.org/10.17159/sajs.2016/20150058

[19] Pozo, R.A., Coulson, T., McCulloch, G., Stronza, A. and Songhurst, A. (2019) Chilli-Briquettes Modify the Temporal Behaviour of Elephants, but Not Their Numbers. Oryx, 53, 100-108. https://doi.org/10.1017/S0030605317001235

[20] Chang'a, A., de Souza, N., Muya, J., Keyyu, J., Mwakatobe, A., Malugu, L., Ndossi, H.P., Konuche, J., Omondi, R., Mpinge, A., Hahn, N., Palminteri, S. and Olson, D. (2016) Scaling-Up the Use of Chili Fences for Reducing Human-Elephant Conflict across Landscapes in Tanzania. Tropical Conservation Science, 9, 921-930. https://doi.org/10.1177/194008291600900220

[21] Gross, E.M., Lahkar, B.P., Subedi, N., Nyirenda, V.R., Lichtenfeld, L.L. and Jakoby, O. (2019) Does Traditional and Advanced Guarding Reduce Crop Losses Due to Wildlife? 
A Comparative Analysis from Africa and Asia. Journal for Nature Conservation, 50, Article ID: 125712. https://doi.org/10.1016/j.jnc.2019.125712

[22] Evans, L.A. and Adams, W.M. (2016) Fencing Elephants: The Hidden Politics of Wildlife Fencing in Laikipia, Kenya. Land Use Policy, 51, 215-228.

https://doi.org/10.1016/j.landusepol.2015.11.008

[23] Hahn, N., Mwakatobe, A., Konuche, J., De Souza, N., Keyyu, J., Goss, M., Chang'a, A., Palminteri, S., Dinerstein, E. and Olson, D. (2017) Unmanned Aerial Vehicles Mitigate Human-Elephant Conflict on the Borders of Tanzanian Parks: A Case Study. Oryx, 51, 513-516. https://doi.org/10.1017/S0030605316000946

[24] Gross, E.M., McRobb, R. and Gross, J. (2016) Cultivating Alternative Crops Reduces Crop Losses Due to African Elephants. Journal of Pest Science, 89, 497-506. https://doi.org/10.1007/s10340-015-0699-2

[25] Somgird, C., Brown, J.L. and Thitaram, C. (2017) Reproductive Control in Elephant: A Tool for Population and Aggression Management. Thai Journal of Veterinary Medicine, 47, 1-6.

http://www.thaiscience.info/journals/Article/TJVM/10983993.pdf

[26] Lueders, I., Young, D., Maree, L., Van der Horst, G., Luther, I., Botha, S., Tindall, B., Fosgate, G., Ganswindt, A. and Bertschinger, H.J. (2017) Effects of GnRH Vaccination in Wild and Captive African Elephant Bulls (Loxodonta africana) on Reproductive Organs and Semen Quality. PLoS ONE, 12, e0178270. https://doi.org/10.1371/journal.pone.0178270

[27] Zitzer, H.R. and Boult, V.L. (2018) Vasectomies of Male African Elephants as a Population Management Tool: A Case Study. Bothalia-African Biodiversity \& Conservation, 48, a2313. https://doi.org/10.4102/abc.v48i2.2313

[28] Buchholtz, E.K., Redmore, L., Fitzgerald, L.A., Stronza, A., Songhurst, A. and McCulloch, G. (2019) Temporal Partitioning and Overlapping Use of a Shared Natural Resource by People and Elephants. Frontiers in Ecology and Evolution, 7, 117. https://doi.org/10.3389/fevo.2019.00117

[29] Nyirenda, V.R., Nkhata, B.A., Tembo, O. and Siamundele, S. (2018) Elephant Crop Damage: Subsistence Farmers' Social Vulnerability, Livelihood Sustainability and Elephant Conservation. Sustainability, 10, 3572. https://doi.org/10.3390/su10103572

[30] Noga, S.R., Kolawole, O.D., Thakadu, O.T. and Masunga, G.S. (2017) Claims and Counterclaims: Institutional Arrangements and Farmers' Response to the Delivery and Adoption of Innovations in the Okavango Delta, Botswana. Journal of Agricultural Education and Extension, 23, 121-139. https://doi.org/10.1080/1389224X.2016.1260485

[31] Evans, L.A. and Adams, W.M. (2018) Elephants as Actors in the Political Ecology of Human-Elephant Conflict. Transactions of the Institute of British Geographers, 43, 630-645. https://doi.org/10.1111/tran.12242

[32] Mumby, H.S. and Plotnik, J.M. (2018) Taking the Elephants' Perspective: Remembering Elephant Behavior, Cognition and Ecology in Human-Elephant Conflict Mitigation. Frontiers in Ecology and Evolution, 6, 122. https://doi.org/10.3389/fevo.2018.00122

[33] Lindsay, K., Chase, M., Landen, K. and Nowak, K. (2017) The Shared Nature of Africa's Elephants. Biological Conservation, 215, 260-267. https://doi.org/10.1016/j.biocon.2017.08.021

[34] Selier, S.A.J., Slotow, R. and Di Minin, E. (2016) The Influence of Socioeconomic Factors on the Densities of High-Value Cross-Border Species, the African Elephant. 
PeerJ, 2016, e2581. https://doi.org/10.7717/peerj.2581

[35] Powell, L.A., Kazahe, U. and Kharuxab, R. (2017) Livestock Farmers Engage in Ecotourism as a Result of Beliefs and Attitudes toward Wildlife on Communal Lands in Namibia. Human Dimensions of Wildlife, 22, 217-230. https://doi.org/10.1080/10871209.2017.1295490

[36] Mayberry, A.L., Hovorka, A.J. and Evans, K.E. (2017) Well-Being Impacts of Human-Elephant Conflict in Khumaga, Botswana: Exploring Visible and Hidden Dimensions. Conservation and Society, 15, 280-291. https://www.jstor.org/stable/26393296

[37] Hacker, C.E. and Miller, L.J. (2016) Zoo Visitor Perceptions, Attitudes, and Conservation Intent after Viewing African Elephants at the San Diego Zoo Safari Park. Zoo Biology, 35, 355-361. https://doi.org/10.1002/zoo.21303

[38] Moolman, L., Ferreira, S.M., Gaylard, A., Zimmerman, D. and Kerley, G.I.H. (2019) The Decline of the Knysna Elephants: Pattern and Hypotheses. South African Journal of Science, 115, 1-7. https://doi.org/10.17159/sajs.2019/4805

[39] Schlossberg, S., Chase, M.J. and Sutcliffe, R. (2019) Evidence of a Growing Elephant Poaching Problem in Botswana. Current Biology, 29, 2222-2228. https://doi.org/10.1016/j.cub.2019.05.061

[40] Chase, M.J., Schlossberg, S., Griffin, C.R., Bouché, P.J.C., Djene, S.W., Elkan, P.W., Ferreira, S., Grossman, F., Kohi, E.M., Landen, K., Omondi, P., Peltier, A., Selier, S.A.J. and Sutcliffe, R. (2016) Continent-Wide Survey Reveals Massive Decline in African Savannah Elephants. PeerJ, 2016, e2354. https://doi.org/10.7717/peerj.2354

[41] Onyango, P.O. and Lesowapir, B. (2016) Demography of a Population with a Long History of Poaching and the Utility of the Individual Identification Technique as a Tool for Monitoring Intermittently Studied Elephant Populations. African Journal of Ecology, 54, 357-364. https://doi.org/10.1111/aje.12297

[42] Rashidi, P., Wang, T., Skidmore, A., Mehdipoor, H., Darvishzadeh, R., Ngene, S., Vrieling, A. and Toxopeus, A.G. (2016) Elephant Poaching Risk Assessed Using Spatial and Non-Spatial Bayesian Models. Ecological Modelling, 338, 60-68. https://doi.org/10.1016/j.ecolmodel.2016.08.002

[43] Beale, C.M., Hauenstein, S., Mduma, S., Frederick, H., Jones, T., Bracebridge, C., Maliti, H., Kija, H. and Kohi, E.M. (2018) Spatial Analysis of Aerial Survey Data Reveals Correlates of Elephant Carcasses within a Heavily Poached Ecosystem. Biological Conservation, 218, 258-267. https://doi.org/10.1016/j.biocon.2017.11.016

[44] Shaffer, M.J. and Bishop, J.A. (2016) Predicting and Preventing Elephant Poaching Incidents through Statistical Analysis, GIS-Based Risk Analysis, and Aerial Surveillance Flight Path Modeling. Tropical Conservation Science, 9, 525-548. https://doi.org/10.1177/194008291600900127

[45] Sibanda, M., Dube, T., Bangamwabo, V.M., Mutanga, O., Shoko, C. and Gumindoga, W. (2016) Understanding the Spatial Distribution of Elephant (Loxodonta africana) Poaching Incidences in the Mid-Zambezi Valley, Zimbabwe Using Geographic Information Systems and Remote Sensing. Geocarto International, 31, 1006-1018. https://doi.org/10.1080/10106049.2015.1094529

[46] Ihwagi, F.W., Wang, T., Wittemyer, G., Skidmore, A.K., Toxopeus, A.G., Ngene, S., King, J., Worden, J., Omondi, P. and Douglas-Hamilton, I. (2015) Using Poaching Levels and Elephant Distribution to Assess the Conservation Efficacy of Private, Communal and Government Land in Northern Kenya. PLoS ONE, 10, e0139079. https://doi.org/10.1371/journal.pone.0139079 
[47] Ihwagi, F.W., Skidmore, A.K., Wang, T., Bastille-Rousseau, G., Toxopeus, A.G. and Douglas-Hamilton, I. (2019) Poaching Lowers Elephant Path Tortuosity: Implications for Conservation. Journal of Wildlife Management, 83, 1022-1031. https://doi.org/10.1002/jwmg.21688

[48] Chiyo, P.I., Obanda, V. and Korir, D.K. (2015) Illegal Tusk Harvest and the Decline of Tusk Size in the African Elephant. Ecology and Evolution, 5, 5216-5229. https://doi.org/10.1002/ece3.1769

[49] Raubenheimer, E.J. and Miniggio, H.D. (2016) Ivory Harvesting Pressure on the Genome of the African Elephant: A Phenotypic Shift to Tusklessness. Head and Neck Pathology, 10, 332-335. https://doi.org/10.1007/s12105-016-0704-y

[50] Goldenberg, S.Z., Douglas-Hamilton, I. and Wittemyer, G. (2016) Vertical Transmission of Social Roles Drives Resilience to Poaching in Elephant Networks. Current Biology, 26, 75-79. https://doi.org/10.1016/j.cub.2015.11.005

[51] Pretorius, Y., Garaï, M.E. and Bates, L.A. (2019) The Status of African Elephant Loxodonta africana Populations in South Africa. Oryx, 53, 757-763. https://doi.org/10.1017/S0030605317001454

[52] Green, S.E., Davidson, Z., Kaaria, T. and Doncaster, C.P. (2018) Do Wildlife Corridors Link or Extend Habitat? Insights from Elephant Use of a Kenyan Wildlife Corridor. African Journal of Ecology, 56, 860-871. https://doi.org/10.1111/aje.12541

[53] Osipova, L., Okello, M.M., Njumbi, S.J., Ngene, S., Western, D., Hayward, M.W. and Balkenhol, N. (2019) Validating Movement Corridors for African Elephants Predicted from Resistance-Based Landscape Connectivity Models. Landscape Ecology, 34, 865-878. https://doi.org/10.1007/s10980-019-00811-0

[54] Ishida, Y., Van Coeverden de Groot, P.J., Leggett, K.E.A., Putnam, A.S., Fox, V.E., Lai, J., Boag, P.T., Georgiadis, N.J. and Roca, A.L. (2016) Genetic Connectivity across Marginal Habitats: The Elephants of the Namib Desert. Ecology and Evolution, 6, 6189-6201. https://doi.org/10.1002/ece3.2352

[55] Zacarias, D., Bini, L.M. and Loyola, R. (2016) Systematic Review on the Conservation Genetics of African Savannah Elephants. PeerJ, 4, e2567.

https://doi.org/10.7717/peerj.2567

[56] Roca, A.L. (2019) African Elephant Genetics: Enigmas and Anomalies. Journal of Genetics, 98, Article No. 83. https://doi.org/10.1007/s12041-019-1125-y

[57] Mondol, S., Moltke, I., Hart, J., Keigwin, M., Brown, L., Stephens, M. and Wasser, S.K. (2015) New Evidence for Hybrid Zones of Forest and Savanna Elephants in Central and West Africa. Molecular Ecology, 24, 6134-6147. https://doi.org/10.1111/mec.13472

[58] Muposhi, V.K., Gandiwa, E., Bartels, P., Makuza, S.M. and Madiri, T.H. (2016) Trophy Hunting and Sustainability: Temporal Dynamics in Trophy Quality and Harvesting Patterns of Wild Herbivores in a Tropical Semi-Arid Savanna Ecosystem. PLoS ONE, 11, e0164429. https://doi.org/10.1371/journal.pone.0164429

[59] Hauenstein, S., Kshatriya, M., Blanc, J., Dormann, C.F. and Beale, C.M. (2019) African Elephant Poaching Rates Correlate with Local Poverty, National Corruption and Global Ivory Price. Nature Communications, 10, Article No. 2242. https://doi.org/10.1038/s41467-019-09993-2

[60] Jung, B.D. (2017) The Tragedy of the Elephants. Wisconsin Law Review, No. 4, 695-737. https://ssrn.com/abstract=3063682

[61] Ogada, D., Botha, A. and Shaw, P. (2016) Ivory Poachers and Poison: Drivers of Africa's Declining Vulture Populations. Oryx, 50, 593-596.

https://doi.org/10.1017/S0030605315001209 
[62] Wasser, S.K., Brown, L., Mailand, C., Mondol, S., Clark, W., Laurie, C. and Weir, B.S. (2015) Genetic Assignment of Large Seizures of Elephant Ivory Reveals Africa's Major Poaching Hotspots. Science, 349, 84-87. https://doi.org/10.1126/science.aaa2457

[63] Kitpipit, T., Thanakiatkrai, P., Penchart, K., Ouithavon, K., Satasook, C. and Linacre, A. (2016) Ivory Species Identification Using Electrophoresis-Based Techniques. Electrophoresis, 37, 3068-3075. https://doi.org/10.1002/elps.201600275

[64] Ziegler, S., Merker, S., Streit, B., Boner, M. and Jacob, D.E. (2016) Towards Understanding Isotope Variability in Elephant Ivory to Establish Isotopic Profiling and Source-Area Determination. Biological Conservation, 197, 154-163. https://doi.org/10.1016/j.biocon.2016.03.008

[65] Seloana, M.Q., Jordaan, J.J., Potgieter, M.J. and Kruger, J.W. (2018) Feeding Patterns of Elephants at the Atherstone Collaborative Nature Reserve. African Journal of Ecology, 56, 445-454. https://doi.org/10.1111/aje.12422

[66] Ward, D., Muller, K. and Shrader, A.M. (2017) Soil Fertility on Granite and Sedimentary Soils Is Associated with Seasonal Differences in Foraging by Elephants. Plant and Soil, 413, 73-81. https://doi.org/10.1007/s11104-016-3067-y

[67] Fullman, T.J., Kiker, G.A., Gaylard, A., Southworth, J., Waylen, P. and Kerley, G.I. (2017) Elephants Respond to Resource Trade-Offs in an Aseasonal System through Daily and Annual Variability in Resource Selection. Koedoe, 59, a1326. https://doi.org/10.4102/koedoe.v59i1.1326

[68] Clegg, B.W. and O’Connor, T.G. (2016) Harvesting and Chewing as Constraints to Forage Consumption by the African Savanna Elephant (Loxodonta africana). Peer), 4, e2469. https://doi.org/10.7717/peerj.2469

[69] Kalumanga, E., Mpanduji, D.G. and Cousins, S.A. (2017) Geophagic Termite Mounds as One of the Resources for African Elephants in Ugalla Game Reserve, Western Tanzania. African Journal of Ecology, 55, 91-100. https://doi.org/10.1111/aje.12326

[70] Muposhi, V.K., Gandiwa, E., Chemura, A., Bartels, P., Makuza, S.M. and Madiri, T.H. (2016) Habitat Heterogeneity Variably Influences Habitat Selection by Wild Herbivores in a Semi-Arid Tropical Savanna Ecosystem. PLoS ONE, 11, e0163084. https://doi.org/10.1371/journal.pone.0163084

[71] Stommel, C., Hofer, H., Grobbel, M. and East, M.L. (2016) Large Mammals in Ruaha National Park, Tanzania, Dig for Water When Water Stops Flowing and Water Bacterial Load Increases. Mammalian Biology, 81, 21-30. https://doi.org/10.1016/j.mambio.2015.08.005

[72] Purdon, A. and Van Aarde, R.J. (2017) Water Provisioning in Kruger National Park Alters Elephant Spatial Utilisation Patterns. Journal of Arid Environments, 141, 45-51. https://doi.org/10.1016/j.jaridenv.2017.01.014

[73] Gara, T.W., Wang, T., Skidmore, A.K., Ngene, S.M., Dube, T. and Sibanda, M. (2017) Elephants Move Faster in Small Fragments of Low Productivity in Amboseli Ecosystems: Kenya. Geocarto International, 32, 1243-1253. https://doi.org/10.1080/10106049.2016.1206625

[74] Purdon, A., Mole, M.A., Chase, M.J. and Van Aarde, R.J. (2018) Partial Migration in Savanna Elephant Populations Distributed across Southern Africa. Scientific Reports, 8, Article No. 11331. https://doi.org/10.1038/s41598-018-29724-9

[75] Panagiotopoulou, O., Pataky, T.C., Day, M., Hensman, M.C., Hensman, S., Hutchinson, J.R. and Clemente, C.J. (2016) Foot Pressure Distributions during Walking 
in African Elephants (Loxodonta africana). Royal Society Open Science, 3, Article ID: 160203. https://doi.org/10.1098/rsos.160203

[76] Rossman, Z.T., Hart, B.L., Greco, B.J., Young, D., Padfield, C., Weidner, L., Gates, J. and Hart, L.A. (2017) When Yawning Occurs in Elephants. Frontiers in Veterinary Science, 4, 22. https://doi.org/10.3389/fvets.2017.00022

[77] Gravett, N., Bhagwandin, A., Sutcliffe, R., Landen, K., Chase, M.J., Lyamin, O.I., Siegel, J.M. and Manger, P.R. (2017) Inactivity/Sleep in Two Wild Free-Roaming African Elephant Matriarchs-Does Large Body Size Make Elephants the Shortest Mammalian Sleepers? PLoS ONE, 12, e0171903. https://doi.org/10.1371/journal.pone.0171903

[78] Wittemyer, G., Keating, L.M., Vollrath, F. and Douglas-Hamilton, I. (2017) Graph Theory Illustrates Spatial and Temporal Features That Structure Elephant Rest Locations and Reflect Risk Perception. Ecography, 40, 598-605.

https://doi.org/10.1111/ecog.02379

[79] Tsalyuk, M., Kilian, W., Reineking, B. and Getz, W.M. (2019) Temporal Variation in Resource Selection of African Elephants Follows Long-Term Variability in Resource Availability. Ecological Monographs, 89, e01348.

https://doi.org/10.1002/ecm.1348

[80] Wato, Y.A., Prins, H.H., Heitkönig, I., Wahungu, G.M., Ngene, S.M., Njumbi, S. and Van Langevelde, F. (2018) Movement Patterns of African Elephants (Loxodonta africana) in a Semi-Arid Savanna Suggest That They Have Information on the Location of Dispersed Water Sources. Frontiers in Ecology and Evolution, 6, 167. https://doi.org/10.3389/fevo.2018.00167

[81] Goldenberg, S.Z., Douglas-Hamilton, I., Daballen, D. and Wittemyer, G. (2017) Challenges of Using Behavior to Monitor Anthropogenic Impacts on Wildlife: A Case Study on Illegal Killing of African Elephants. Animal Conservation, 20, 215-224. https://doi.org/10.1111/acv.12309

[82] Szott, I.D., Pretorius, Y. and Koyama, N.F. (2019) Behavioural Changes in African Elephants in Response to Wildlife Tourism. Journal of Zoology, 308, 164-174. https://doi.org/10.1111/jzo.12661

[83] Miller, A.K., Hensman, M.C., Hensman, S., Schultz, K., Reid, P., Shore, M., Brown, J., Furthon, K.G. and Lee, S. (2015) African Elephants (Loxodonta africana) Can Detect TNT Using Olfaction: Implications for Biosensor Application. Applied Animal Behaviour Science, 171, 177-183. https://doi.org/10.1016/j.applanim.2015.08.003

[84] McArthur, C., Finnerty, P.B., Schmitt, M.H., Shuttleworth, A. and Shrader, A.M. (2019) Plant Volatiles Are a Salient Cue for Foraging Mammals: Elephants Target Preferred Plants Despite Background Plant Odour. Animal Behaviour, 155, 199-216. https://doi.org/10.1016/j.anbehav.2019.07.002

[85] Mole, M.A., DÁraujo, S.R., Van Aarde, R.J., Mitchell, D. and Fuller, A. (2016) Coping with Heat: Behavioural and Physiological Responses of Savanna Elephants in Their Natural Habitat. Conservation Physiology, 4, cow044. https://doi.org/10.1093/conphys/cow044

[86] Mortimer, B., Rees, W.L., Koelemeijer, P. and Nissen-Meyer, T. (2018) Classifying Elephant Behaviour through Seismic Vibrations. Current Biology, 28, R547-R548. https://doi.org/10.1016/j.cub.2018.03.062

[87] Fishlock, V., Caldwell, C. and Lee, P.C. (2016) Elephant Resource-Use Traditions. Animal Cognition, 19, 429-433. https://doi.org/10.1007/s10071-015-0921-x 
[88] Bastille-Rousseau, G. and Wittemyer, G. (2019) Leveraging Multidimensional Heterogeneity in Resource Selection to Define Movement Tactics of Animals. Ecology Letters, 22, 1417-1427. https://doi.org/10.1111/ele.13327

[89] McKnight, B.L. (2015) Relationship between Group Dynamics and Spatial Distribution of African Elephants in a Semi-Arid Environment. African Journal of Ecology, 53, 439-446. https://doi.org/10.1111/aje.12223

[90] Goldenberg, S.Z. and Wittemyer, G. (2019) Elephant Behavior toward the Dead: A Review and Insights from Field Observations. Primates, 61, 119-128. https://doi.org/10.1007/s10329-019-00766-5

[91] Wyse, J.M., Hardy, I.C., Yon, L. and Mesterton-Gibbons, M. (2017) The Impact of Competition on Elephant Musth Strategies: A Game-Theoretic Model. Journal of Theoretical Biology, 417, 109-130. https://doi.org/10.1016/j.jtbi.2017.01.025

[92] Goldenberg, S.Z. and Wittemyer, G. (2017) Orphaned Female Elephant Social Bonds Reflect Lack of Access to Mature Adults. Scientific Reports, 7, Article No. 14408. https://doi.org/10.1038/s41598-017-14712-2

[93] Goldenberg, S.Z., Owen, M.A., Brown, J.L., Wittemyer, G., Oo, Z.M. and Leimgruber, P. (2019) Increasing Conservation Translocation Success by Building Social Functionality in Released Populations. Global Ecology and Conservation, 18, e00604. https://doi.org/10.1016/j.gecco.2019.e00604

[94] Prado-Oviedo, N.A., Bonaparte-Saller, M.K., Malloy, E.J., Meehan, C.L., Mench, J.A., Carlstead, K. and Brown, J.L. (2016) Evaluation of Demographics and Social Life Events of Asian (Elephas maximus) and African Elephants (Loxodonta africana) in North American Zoos. PLoS ONE, 11, e0154750. https://doi.org/10.1371/journal.pone.0154750

[95] Baotic, A. and Stoeger, A.S. (2017) Sexual Dimorphism in African Elephant Social Rumbles. PLoS ONE, 12, e0177411. https://doi.org/10.1371/journal.pone.0177411

[96] Stoeger, A.S. and Baotic, A. (2017) Male African Elephants Discriminate and Prefer Vocalizations of Unfamiliar Females. Scientific Reports, 7, Article No. 46414. https://doi.org/10.1038/srep46414

[97] Stoeger, A.S. and Baotic, A. (2016) Information Content and Acoustic Structure of Male African Elephant Social Rumbles. Scientific Reports, 6, Article No. 27585. https://doi.org/10.1038/srep27585

[98] Pardo, M.A., Poole, J.H., Stoeger, A.S., Wrege, P.H., O'Connell-Rodwell, C.E., Padmalal, U.K. and de Silva, S. (2019) Differences in Combinatorial Calls among the 3 Elephant Species Cannot Be Explained by Phylogeny. Behavioral Ecology, 30, 809-820. https://doi.org/10.1093/beheco/arz018

[99] Williams, E., Carter, A., Hall, C. and Bremner-Harrison, S. (2019) Social Interactions in Zoo-Housed Elephants: Factors Affecting Social Relationships. Animals, 9, 747. https://doi.org/10.3390/ani9100747

[100] Williams, E., Carter, A., Hall, C. and Bremner-Harrison, S. (2019) Exploring the Relationship between Personality and Social Interactions in Zoo-Housed Elephants: Incorporation of Keeper Expertise. Applied Animal Behaviour Science, 221, Article ID: 104876. https://doi.org/10.1016/j.applanim.2019.104876

[101] Vicino, G.A. and Marcacci, E.S. (2015) Intensity of Play Behavior as a Potential Measure of Welfare: A Novel Method for Quantifying the Integrated Intensity of Behavior in African Elephants. Zoo Biology, 34, 492-496. https://doi.org/10.1002/zoo.21238

[102] Meehan, C.L., Mench, J.A., Carlstead, K. and Hogan, J.N. (2016) Determining Connections between the Daily Lives of Zoo Elephants and Their Welfare: An Epi- 
demiological Approach. PLoS ONE, 11, e0158124. https://doi.org/10.1371/journal.pone.0158124

[103] Meehan, C.L., Hogan, J.N., Bonaparte-Saller, M.K. and Mench, J.A. (2016) Housing and Social Environments of African (Loxodonta africana) and Asian (Elephas maximus) Elephants in North American Zoos. PLoS ONE, 11, e0146703. https://doi.org/10.1371/journal.pone.0146703

[104] Martin, R.A. and Melfi, V. (2016) A Comparison of Zoo Animal Behavior in the Presence of Familiar and Unfamiliar People. Journal of Applied Animal Welfare Science, 19, 234-244. https://doi.org/10.1080/10888705.2015.1129907

[105] Holdgate, M.R., Meehan, C.L., Hogan, J.N., Miller, L.J., Rushen, J., de Passillé, A.M., Soltis, J., Andrews, J. and Shepherdson, D.J. (2016) Recumbence Behavior in Zoo Elephants: Determination of Patterns and Frequency of Recumbent Rest and Associated Environmental and Social Factors. PLOS ONE, 11, e0153301. https://doi.org/10.1371/journal.pone.0153301

[106] Schiffmann, C., Hård, T., Hjelm, M. and Clauss, M. (2019) Soft and Persistent-The Influence of Sand-Flooring and Calves on the Resting Behavior of a Zoo-Kept African Elephant (Loxodonta africana) Group. Zoo Biology, 39, 56-62. https://doi.org/10.1002/zoo.21521

[107] Boyle, S.A., Roberts, B., Pope, B.M., Blake, M.R., Leavelle, S.E., Marshall, J.J., Smith, A., Hadicke, A., Falcone, J.F., Knott, K. and Kouba, A.J. (2015) Assessment of Flooring Renovations on African Elephant (Loxodonta africana) Behavior and Glucocorticoid Response. PLoS ONE, 10, e0141009.

https://doi.org/10.1371/journal.pone.0141009

[108] Soltis, J., King, L., Vollrath, F. and Douglas-Hamilton, I. (2016) Accelerometers and Simple Algorithms Identify Activity Budgets and Body Orientation in African Elephants Loxodonta africana. Endangered Species Research, 31, 1-12. https://doi.org/10.3354/esr00746

[109] Gara, T.W., Wang, T., Skidmore, A.K., Zengeya, F.M., Ngene, S.M., Murwira, A. and Ndaimani, H. (2017) Understanding the Effect of Landscape Fragmentation and Vegetation Productivity on Elephant Habitat Utilization in Amboseli Ecosystem, Kenya. African Journal of Ecology, 55, 259-269. https://doi.org/10.1111/aje.12346

[110] Watson, L.H., Cameron, M.J. and Iifo, F. (2019) Elephant Herbivory of Knob-Thorn (Senegalia nigrescens) and Ivory Palm (Hyphaene petersiana) in Bwabwata National Park, Caprivi, Namibia: The Role of Ivory Palm as a Biotic Refuge. African Journal of Ecology, 58, 14-22. https://doi.org/10.1111/aje.12681

[111] Salako, V.K., Azihou, A.F., Assogbadjo, A.E., Houéhanou, T.D., Kassa, B.D. and Glèlè Kakaï, R.L. (2016) Elephant-Induced Damage Drives Spatial Isolation of the Dioecious Palm Borassus aethiopum Mart. (Arecaceae) in the Pendjari National Park, Benin. African Journal of Ecology, 54, 9-19. https://doi.org/10.1111/aje.12253

[112] Salako, V.K., Houehanou, T.H., Yessoufou, K., Assogbadjo, A.E., Akoègninou, A. and Kakai, R.L.G. (2017) Patterns of Elephant Utilization of Borassus aethiopum Mart. and Its Stand Structure in the Pendjari National Park, Benin, West Africa. Tropical Ecology, 58, 425-437. http://www.tropecol.com/pdf/open/PDF 58 2/18.\%20Salako\%20et\%20al.pdf

[113] Hema, E.M., Barnes, R.F., Di Vittorio, M., Luiselli, L. and Guenda, W. (2017) Selective Disturbance by Elephants (Loxodonta africana) on Eight Tree Species in a West African Savannah. Ecological Research, 32, 205-214.

https://doi.org/10.1007/s11284-016-1431-2 
[114] Ndoro, O., Mashapa, C., Kativu, S. and Gandiwa, E. (2016) Impact of African Elephant on Baobab along a Surface Water Availability Gradient in Mana Pools National Park, Zimbabwe. Tropical Ecology, 57, 333-341.

https://www.researchgate.net/profile/Edson Gandiwa/publication/265086035 Impa ct of African elephant on baobab along a surface water availability gradient $\mathrm{i}$ n Mana Pools National Park Zimbabwe/links/5667da4308aea62726ee9d79/Impa ct-of-African-elephant-on-baobab-along-a-surface-water-availability-gradient-in-M ana-Pools-National-Park-Zimbabwe.pdf

[115] Cook, R.M., Witkowski, E.T.F., Helm, C.V., Henley, M.D. and Parrini, F. (2017) Recent Exposure to African Elephants after a Century of Exclusion: Rapid Accumulation of Marula Tree Impact and Mortality, and Poor Regeneration. Forest Ecology and Management, 401, 107-116. https://doi.org/10.1016/j.foreco.2017.07.006

[116] Mograbi, P.J., Asner, G.P., Witkowski, E.T., Erasmus, B.F., Wessels, K.J., Mathieu, R. and Vaughn, N.R. (2017) Humans and Elephants as Treefall Drivers in African Savannas. Ecography, 40, 1274-1284. https://doi.org/10.1111/ecog.02549

[117] Tripathi, H.G., Mzumara, T.I., Martin, R.O., Parr, C.L., Phiri, C. and Ryan, C.M. (2019) Dissimilar Effects of Human and Elephant Disturbance on Woodland Structure and Functional Bird Diversity in the Mopane Woodlands of Zambia. Landscape Ecology, 34, 357-371. https://doi.org/10.1007/s10980-019-00774-2

[118] Parker, D.M. (2017) The Composition and Complexity of the Woody and Succulent Components of Albany Thicket with and without Elephants. South African Journal of Botany, 112, 19-28. https://doi.org/10.1016/j.sajb.2017.05.004

[119] Daskin, J.H., Stalmans, M. and Pringle, R.M. (2016) Ecological Legacies of Civil War: 35-Year Increase in Savanna Tree Cover Following Wholesale Large-Mammal Declines. Journal of Ecology, 104, 79-89. https://doi.org/10.1111/1365-2745.12483

[120] Fox, J.T., Vandewalle, M.E. and Alexander, K.A. (2017) Land Cover Change in Northern Botswana: The Influence of Climate, Fire, and Elephants on Semi-Arid Savanna Woodlands. Land, 6, 73. https://doi.org/10.3390/land6040073

[121] Katani, J.Z., Mustalahti, I., Mukama, K. and Zahabu, E. (2016) Participatory Forest Carbon Assessment in South-Eastern Tanzania: Experiences, Costs and Implications for REDD+ Initiatives. Oryx, 50, 523-532.

https://doi.org/10.1017/S0030605315000174

[122] Coverdale, T.C., Kartzinel, T.R., Grabowski, K.L., Shriver, R.K., Hassan, A.A., Goheen, J.R., Palmer, T.M. and Pringle, R.M. (2016) Elephants in the Understory: Opposing Direct and Indirect Effects of Consumption and Ecosystem Engineering by Megaherbivores. Ecology, 97, 3219-3230. https://doi.org/10.1002/ecy.1557

[123] de Boer, W.F., Van Oort, J.W., Grover, M. and Peel, M.J. (2015) Elephant-Mediated Habitat Modifications and Changes in Herbivore Species Assemblages in Sabi Sand, South Africa. European Journal of Wildlife Research, 61, 491-503. https://doi.org/10.1007/s10344-015-0919-3

[124] Edge, A., Henley, M., Daday, J. and Schulte, B.A. (2017) Examining Human Perception of Elephants and Large Trees for Insights into Conservation of an African Savanna Ecosystem. Human Dimensions of Wildlife, 22, 231-245. https://doi.org/10.1080/10871209.2017.1298168

[125] Henley, M.D. and Cook, R.M. (2019) The Management Dilemma: Removing Elephants to Save Large Trees. Koedoe, 61, a1564.

https://doi.org/10.4102/koedoe.v61i1.1564 
[126] Derham, K., Henley, M.D. and Schulte, B.A. (2016) Wire Netting Reduces African Elephant (Loxodonta africana) Impact to Selected Trees in South Africa. Koedoe, 58, a1327. https://doi.org/10.4102/koedoe.v58i1.1327

[127] Asner, G.P., Vaughn, N., Smit, I.P. and Levick, S. (2016) Ecosystem-Scale Effects of Megafauna in African Savannas. Ecography, 39, 240-252.

https://doi.org/10.1111/ecog.01640

[128] Pasenko, M.R. (2017) Quantitative and Qualitative Data of Footprints Produced by Asian (Elephas maximus) and African (Loxodonta africana) Elephants and with a Discussion of Significance towards Fossilized Proboscidean Footprints. Quaternary International, 443, 221-227. https://doi.org/10.1016/j.quaint.2017.05.030

[129] Remmers, W., Gameiro, J., Schaberl, I. and Clausnitzer, V. (2017) Elephant (Loxodonta africana) Footprints as Habitat for Aquatic Macroinvertebrate Communities in Kibale National Park, South-West Uganda. African Journal of Ecology, 55, 342-351. https://doi.org/10.1111/aje.12358

[130] Bunney, K., Bond, W.J. and Henley, M. (2017) Seed Dispersal Kernel of the Largest Surviving Megaherbivore-The African Savanna Elephant. Biotropica, 49, 395-401. https://doi.org/10.1111/btp.12423

[131] Spanbauer, B.R. and Adler, G.H. (2015) Seed Protection through Dispersal by African Savannah Elephants (Loxodonta africana africana) in Northern Tanzania. African Journal of Ecology, 53, 496-501. https://doi.org/10.1111/aje.12239

[132] Stanbrook, R.A. (2018) Assessing the Nutrient Status of Elephant Dung in the Aberdare National Park, Kenya. Pachyderm, No. 59, 86-90.

https://pdfs.semanticscholar.org/bab2/3b65707d1caa650d5796bc8a61ee58f1bb66.pd $\underline{\mathrm{f} \text { ? } \mathrm{ga}=2.6088627 .1020508752 .1594717976-234245446.1560788206}$

[133] Edwards, K.L., Miller, M.A., Carlstead, K. and Brown, J.L. (2019) Relationships between Housing and Management Factors and Clinical Health Events in Elephants in North American Zoos. PLOS ONE, 14, e0217774. https://doi.org/10.1371/journal.pone.0217774

[134] Brown, J.L., Carlstead, K., Bray, J.D., Dickey, D., Farin, C. and Ange-van Heugten, K. (2019) Individual and Environmental Risk Factors Associated with Fecal Glucocorticoid Metabolite Concentrations in Zoo-Housed Asian and African Elephants. PLOS ONE, 14, e0217326. https://doi.org/10.1371/journal.pone.0217326

[135] Hunninck, L., Ringstad, I.H., Jackson, C.R., May, R., Fossøy, F., Uiseb, K., Killian, W., Palme, R. and Røskaft, E. (2017) Being Stressed Outside the Park-Conservation of African Elephants (Loxodonta africana) in Namibia. Conservation Physiology, 5, cox067. https://doi.org/10.1093/conphys/cox067

[136] Kioko, J., Taylor, K., Milne, H.J., Hayes, K.Z. and Kiffner, C. (2017) Temporal Gland Secretion in African Elephants (Loxodonta africana). Mammalian Biology, 82, 34-40. https://doi.org/10.1016/j.mambio.2016.07.005

[137] Hartley, M. and Stanley, C. (2016) Survey of Reproduction and Calf Rearing in Asian and African Elephants in Europe. Journal of Zoo and Aquarium Research, 4, 139-146.

[138] Lee, P.C., Fishlock, V., Webber, C.E. and Moss, C.J. (2016) The Reproductive Advantages of a Long Life: Longevity and Senescence in Wild Female African Elephants. Behavioral Ecology and Sociobiology, 70, 337-345.

https://doi.org/10.1007/s00265-015-2051-5

[139] Chave, E., Edwards, K.L., Paris, S., Prado, N., Morfeld, K.A. and Brown, J.L. (2019) Variation in Metabolic Factors and Gonadal, Pituitary, Thyroid, and Adrenal Hormones in Association with Musth in African and Asian Elephant Bulls. General and 
Comparative Endocrinology, 276, 1-13.

https://doi.org/10.1016/j.ygcen.2019.02.005

[140] Brown, J.L., Paris, S., Prado-Oviedo, N.A., Meehan, C.L., Hogan, J.N., Morfeld, K.A. and Carlstead, K. (2016) Reproductive Health Assessment of Female Elephants in North American Zoos and Association of Husbandry Practices with Reproductive Dysfunction in African Elephants (Loxodonta africana). PLoS ONE, 11, e0145673. https://doi.org/10.1371/journal.pone.0145673

[141] Prado, N.A., Keady, M., Oestmann, A., Steinbeiser, C.M. and Brown, J.L. (2019) Hyperprolactinemic African Elephant (Loxodonta africana) Females Exhibit Elevated Dopamine, Oxytocin and Serotonin Concentrations Compared to Normal Cycling and Noncycling, Low Prolactin Elephants. Biology of Reproduction, 100, 1549-1560. https://doi.org/10.1093/biolre/ioz036

[142] Miller, L.J., Chase, M.J. and Hacker, C.E. (2016) A Comparison of Walking Rates between Wild and Zoo African Elephants. Journal of Applied Animal Welfare Science, 19, 271-279. https://doi.org/10.1080/10888705.2015.1137755

[143] Morfeld, K.A., Meehan, C.L., Hogan, J.N. and Brown, J.L. (2016) Assessment of Body Condition in African (Loxodonta africana) and Asian (Elephas maximus) Elephants in North American Zoos and Management Practices Associated with High Body Condition Scores. PLoS ONE, 11, e0155146.

https://doi.org/10.1371/journal.pone.0155146

[144] Miller, M.A., Hogan, J.N. and Meehan, C.L. (2016) Housing and Demographic Risk Factors Impacting Foot and Musculoskeletal Health in African Elephants [Loxodonta africana] and Asian Elephants [Elephas maximus] in North American Zoos. PLOS ONE, 11, e0155223. https://doi.org/10.1371/journal.pone.0155223

[145] Kerr, T.J., de Waal, C.R., Buss, P.E., Hofmeyr, J., Lyashchenko, K.P. and Miller, M.A. (2019) Seroprevalence of Mycobacterium tuberculosis Complex in Free-Ranging African Elephants (Loxodonta africana) in Kruger National Park, South Africa. Journal of Wildlife Diseases, 55, 923-927. https://doi.org/10.7589/2018-12-292

[146] Stacy, N.I., Isaza, R. and Wiedner, E. (2017) First Report of Changes in Leukocyte Morphology in Response to Inflammatory Conditions in Asian and African Elephants (Elephas maximus and Loxodonta africana). PLoS ONE, 12, e0185277. https://doi.org/10.1371/journal.pone.0185277

[147] Parker, I.S.C. (2017) A Pathological Condition in Elephant Dentition. Pachyderm, No. 58, 51-57. https://pdfs.semanticscholar.org/a327/8dbd36fe06cb990b17e6e66f702a4a5257a7.pdf ? ga=2.246204036.1020508752.1594717976-234245446.1560788206

[148] Sim, R.R., Stringer, E., Donovan, D., Chappell, R., Flora, P., Hall, J., Pillay, S., Willis, B.G. and McCain, S. (2017) Use of Composite Materials as a Component of Tusk Fracture Management In an Asian Elephant (Elephas maximus) and an African Elephant (Loxodonta africana). Journal of Zoo and Wildlife Medicine, 48, 891-896. https://doi.org/10.1638/2016-0212.1

[149] Nichols, C.A., Vandewalle, M.E. and Alexander, K.A. (2017) Emerging Threats to Dryland Forest Resources: Elephants and Fire Are Only Part of the Story. Forestry: An International Journal of Forest Research, 90, 473-484. https://doi.org/10.1093/forestry/cpx010

[150] Fritz, H. (2017) Long-Term Field Studies of Elephants: Understanding the Ecology and Conservation of a Long-Lived Ecosystem Engineer. Journal of Mammalogy, 98, 603-611. https://doi.org/10.1093/jmammal/gyx023 